\title{
The Problem of the Invisible in Education
}

\author{
Aleksander M. Sidorkin* and Artem M. Kulakov* \\ Institute of Education, Higher School of Economics \\ Building 10, 16 Potapovskiy Pereulok, Moscow, 101000, Russia
}

Received 25.08.2015, received in revised form 31.08.2015, accepted 23.10.2015

The paper presents a theoretical perspective based on the assumption that we deal with the "problem of the invisible" in education. Modern medicine would be impossible without the invention of microscope that made previously invisible class of organisms visible. The authors assume that in educational research we are able neither to detect a certain kind of phenomena nor measure it, the phenomenon being the relations among the participants of the educational process. The structure of relations may dramatically affect the impact of various educational interventions, which on average may produce low or contradictory effect sizes. Human relations may be the ultimate hidden variable of the education research.

Keywords: pedagogy of relations, the invisible, educational research.

DOI: 10.17516/1997-1370-2015-8-11-2632-2637.

Research area: pedagogy, psychology.

Contemporary education faces significant barriers in its development, the barriers being inability to solve certain obvious problems. There can be distinguished four main barriers:

1. Non-dissemination of the best practices. When we try to disseminate some practice of an outstanding teacher, school, or administration, it is either disseminated or not. However, its positive effects considerably weaken and sometimes fizzle out. Roughly speaking, there are two approaches to innovations dissemination. One is exact implementation of a successful practice, implementation fidelity being its priority. The other view emphasizes the necessity "for improvements for one's own needs" (See, for example, Rogers, 2005). However, either of the two approaches cause the waves of innovative approaches and methods that lead to brilliant results in one place but then lose all (or almost all) their force in the course of penetration to mass practice. We do not know why this happens in education, but we know that in other industries those who are engaged in them adopt new methods from each other in a more or less routine way.

2. Minimal effects of all the reforms and impacts. The size of the effect is the evaluation of statistical power, that is, in fact, the strength of interrelation between variables. In education there are no strong effect sizes (Hattie, 2009).

(c) Siberian Federal University. All rights reserved

* Corresponding author E-mail address: asidorkin@hse.ru 
That is in practice there are no breakthrough methods or technologies in education.

3. Unexplainable "dynamic conservatism" of educational organizations. In his book Larry Cuban, professor of Stanford University, talks about "dynamic conservatism" of education. According to him, education is not intrinsically conservative, as, for example, when educational organizations refuse to react to external stimuli. They do react to them, but wish everything remained the same. They adapt by adopting those innovations that lead to no changes. Larry Cuban identified this phenomenon, tries to explain it, but does not give its thorough explanation. It is not clear why people employed in other areas often adopt innovations resulting in a clear advantage, and thus they really change their practice. However, it is not so in education. We have no idea why this happens but we are aware of the fact.

4. Dependence of any practice's effectiveness on the context (the euphemism of complexity). For example, a common question of students of pedagogical specialties is "How to behave with children? Should we smile at children and be friendly with them or is it better to be strict with them?". The answer frequently given is "It depends on the context". In reality, this means that we either do not know the answer or do not understand how to explain it. In general, when the answer boils down to the context of complexity it means that we do not know the answer to the question. Or rather, we cannot turn it into alienable knowledge. The phenomenon of unspeakable knowledge is widespread in pedagogy: we understand and guess much but cannot explain this knowledge at the level of intuitive experience. Or when we use the concept of complex dynamic emergent systems in research discourse it is just a matter of designation of our ignorance of the behavior of a certain system.
One could not say that educational science is in its terrible crisis. On the contrary, its role in informing about practice is growing; the number of good research is also growing. We know much more about how educational systems operate and develop and we are even getting an idea about probable trends of development. However, we must not forget that we are facing a thorough mystery. We probably deal with some "blind spot".

\section{An parallel \\ from medical history}

The famous Roman physician Galen (the 2nd century BC) developed the theory of miasmas, according to which catching diseases spread from poor air. The theory was dominant till the XIX century, the time when Louis Pasteur developed the theory of pathogens, according to which microorganisms, not smells that cause the diseases. Galen's theory was not just a misconception. It cost the society enormously expensive. A huge part of the population (up to half of the population) died from mass infections in Europe in Middle Ages. This led to economic decline, regressive political phenomena.

Dr. Ignaz Semmelweis, who worked in one of Vienna hospitals in the period from 1856 to 1850 , found out that mortality rate in childbirth in the hospital is much higher than that at homes (30-50\%). In the hospital the doctors, who helped the women in labour, often autopsied corpses the same day but did not disinfect their hands, thus infecting the women in labour with catching diseases. The doctors did not do this deliberately; they just did not know (Piper, 2007). Yet we have known about microorganisms since 1665 . In the middle of the XVII century the Dutchman Antonie van Leeuwenhoek saw microorganisms through the microscope. 200 years passed between the discovery of microbes and the theory of pathogens, and 80 years passed before penicillin 
was discovered. This example confirms that it may take a very long time between the discovery of the new and its practical application. Yet one cannot make hypotheses about the invisible. It was impossible to draw a conclusion about the relationship of microbes and spread of infections before the invention of special optics because we knew nothing about the existence of microbes. If something is invisible it does not exist for you or, in other words, there is the unexplained, a mystery.

However, to see with one's own eyes does not mean to see theoretically. These 200 years between the events give an important example: it is possible to see something without attaching importance to it. The difference between the physical vision and the theoretical one is very significant for us here. We can say that the time gap is most likely between them.

\section{Hypothesis}

Perhaps we just do not see some sort of a phenomenon in education. Or we physically see it but do not recognize its role. So, we have not learnt to build it in our theoretical horizon of explanation. We are probably in that transition period of 200 years between the discovery of microbes and the theory of pathogens. We (the society) might possibly have an epistemological "blind spot", and namely the things we tend not to notice or attach vital importance. What if we are on the verge of a new discovery of this phenomenon?

Humanity as a biological species has other "blind spots", too; they are very numerous. Humans cannot see microbes and the most part of the light spectrum; they do not hear ultrasound, do not feel radiation. They very poorly estimate the probability of events, risks. They see regularities where there are none. Conversely, they often cannot directly estimate causality. Guided by stereotyped complexes, instincts, conspiracy theories and ill will, they poorly assess the causality of the phenomena. We have absolutely no statistical sensory organ and we are rather blind to large amounts of data. Undoubtedly, we invented many tools and crutches to compensate for our weaknesses. Yet it would be ridiculous to think that this process is complete, or that we even know about all our limitations.

We may have another blind spot. It is termed entic bias (the term is suggested by Charles Bingham). In the physical world there are things, their properties, interactions, and our actions towards them. They are very important for us in the process of our evolution. All spoken languages have nouns, verbs, adjectives - the units to describe objects, their properties, and actions towards them. This structure of language is pragmatic and utilitarian; it helps to describe the objects as our thinking is directly derived from physical activity. Explicit thinking is the organ of object activity. Explicit part of our thinking serves the activity. Understanding of social relations is displaced into the sphere of tacit or implicit thinking.

It is evolutionary advantageous not to notice one's own culture, not to be aware of the relationship matrix as it is resourcefully wasteful for our brain. Our inclination for paying greater attention to things but not relations is probably biologically determined.

Presumably, there may be a relational ontology which is not the ontology of things but the ontology of relations. Relations are primary in it and the activities beyond the relations are meaningless. The identity of action " $\mathrm{A}$ " and action " $\mathrm{B}$ " is not always consistent. One and the same action in different systems may be directly opposed in their meaning and sense, direction and result. It is worthwhile referring to the example of the students' question about the pattern of behavior towards children 
again. "Friendliness" or, vice versa, strictness with children may have different meanings in different systems. The distinction between meaning and sense (Frege, 1997) tries to explain it in semiotics. If all this is assumed, the mysteries of educational science can be explained.

\section{Background}

It cannot be said that the role of relations in education and human life in general has never been given the focus of research. On the contrary, the problem has a long history, a full description of which goes far beyond the scope of this article. However, we consider it necessary to briefly mention a few names relevant to the ontology of relations. Martin Buber in his book "Ich und Du" intentionally worked out new ontology, taking relations into account: "Im Anfang ist die Beziehung" (In the beginning was the relation). Bakhtin, Dewey, Gadamer and Heidegger considered non-entic, relational aspect of life in one form or another. Makarenko was the first to use the expression "pedagogy of relations" but did not develop any theory concerning it. Feminist philosophers of the XX century, N. Noddings, J.R. Martin, C. Gilligan pointed out that entic bias is more inherent to a masculine than feminine view of the world. Finally, Frank Margonis from the University of Utah was the first who introduced the term "pedagogy of relations" in English literature.

In 2004, the group of authors issued the Manifesto of relational pedagogy

1. A relation is more real than the things it brings together. Human beings and non-human things acquire reality only in relation to other beings and things.

2. The self is a knot in the web of multiple intersecting relations; pull relations out of the web, and find no self. We do not have relations; relations have us.
3. Authority and knowledge are not something one has, but relations, which require others to enact.

4. Human relations exist in and through shared practices.

5. Relations are complex; they may not be described in single utterances. To describe a relation is to produce a multivoiced text.

6. Relations are primary; actions are secondary. Human words and actions have no authentic meaning; they acquire meaning only in a context of specific relations.

7. Teaching is building educational relations. Aims of teaching and outcomes of learning can both be defined as specific forms of relations to oneself, people around the students, and the larger world.

8. Educational relation is different from any other; its nature is transitional. Educational relation exists to include the student in a wider web of relations beyond the limits of the educational relation.

9. Relations are not necessarily good; human relationality is not an ethical value. Domination is as relational as love.

\section{On working out a research program}

It is peculiar for the Russian pedagogy to deduce normativity from philosophical reasoning. We believe that it is necessary to travel all the way from theoretical constructs to empirical results and only then deduce the norms.

It is necessary to develop the theory of relational matrix. There are layers of relations: economical, authoritative, cultural, and possibly others. They hardly superimpose on each other. We have no idea how they interact and how they form a semiotic field of meaning.

There is a semiotic field on which expressions, statements and actions, that have been assigned a meaning, superimpose. There is the need to design 
tools, measuring quality, direction and intensity of relations inside organizations. At present there is an advanced apparatus of anthropological and cultural methods of description, but still we have very few measuring tools. For example, we cannot answer the question: "What units can express relations?".

Albert Bandura introduced the concept of reciprocal determinism, implying that our traditional view on causality won't work in social sciences. It is despite the fact that we are always in search of causality. In social sciences and in pedagogy, in particular, there are many correlational studies ideally searching for identification of causality relations. Bandura's theory states that in the social world factors interact with each other; they reinforce or weaken each other, but one factor is not necessarily the cause of another.

\section{Another medical analogy}

Many drugs show zero efficiency on a large random sample. However, they are effective on a sample with a certain genetic type. The methodology of clinical trials makes the genetic diversity phenomenon unobserved. Science does not only eliminate blind spots but also creates new ones (for example, when it assumes that people are identical in terms of influence of drugs). In recent years there have been attempts to count up the results of some clinical trials separately on different genotypes. For example, the medication may turn out to be effective for the residents of South-East Asia, but non-effective for the Europeans, or vice versa.
If we abstractly consider pedagogical action "A", its observed effect is " 1 " but only in system $\mathrm{X}$. In system $\mathrm{Y}$ the same action "A" has the effect of "- 1 ". If approximately the same number of systems $\mathrm{X}$ and $\mathrm{Y}$ is measured, then the average effect of action "A" tends to zero. However, this does not mean that action "A" actually has zero effect. It was just measured so, without considering the invisible context. A classic example from the sphere of education is constructivism in pedagogy, the central idea being the idea that knowledge cannot be imparted to students in readiness for use. One can only create pedagogical conditions for successful self-construction and self-increase of the students' knowledge. This works at schools with children from the families with high cultural capital. If the children have some deficiencies in their basic literacy knowledge they fill it using the family's cultural resources. At schools with children from very poor families with low socioeconomic status and cultural capital the pedagogy of constructivism won't work. The children in such situations can take knowledge from nowhere else but from school. Such children should be taught basic literacy first.

\section{What can a relational paradigm give us?}

If we had a typology of social relations, we might search for the actions that are effective only for a certain type of systems.

If we understood the logic of the systems evolution, we would improve or change the ecosystems of relations and would not ping-pong the regressions.

\section{References}

Bingham, C.W. \& Sidorkin, A.M. (Eds). No education without relations. Peter Lang, 2004.

Cuban, L. Inside the black box of classroom: practice change without reform in American education. Harvard Education Press, 2013.

Frege, G. Smysl i znachenie [On sense and reference / On sense and meaning]. Frege G., Izbrannye raboty [Selected works]. Moscow, House of intellectual books, 1997. 
Hattie, J. Visible Learning: A Synthesis of Over 800 Meta-Analyses Relating to Achievement. Routledge, 2009.

Piper, J. Motherkillers. Brighton, Book Guild, 2007.

\title{
Проблема невидимого в образовании
}

\author{
А.М. Сидоркин, А.М. Кулаков \\ Институт образования НИУ ВШЭ
}

Россия, 101000, Москва, Потаповский переулок, 16, стр. 10

В статье представлена теоретическая позиция, основанная на предположении, что в образовании мы имеем дело с «проблемой невидимого.» Современная медицина была бы невозможнойбез изобретениямикроскопа, которыйсделал ранееневидимый классорганизмов видимым. Утверждение авторов состоит в том, что в педагогических исследованиях мы не в состоянии обнаружить определенный вид феноменов, и тем более измерить его: отношения между участниками образовательного процесса. Структура отношений может существенно повлиять на воздействие различных образовательных мероприятий, которые в среднем могут производить слабые или противоречивые эффекты. Человеческие отнотения могут быть главной скрытой переменной в исследованиях в области образования.

Ключевые слова: педагогика отношений, невидимое, исследования в области образования.

Научная специальность: 13.00.00 - педагогические науки, 19.00.00 - психологические науки. 